Arab Univ. J. Agric. Sci., Ain Shams Univ., Cairo, 13(2), 441 - 452, 2005

\title{
EFFECT OF IN VITRO PRESERVATION ON THE RAPD PROFILES IN "KORONAIKI" AND "KALAMATA" OLIVE CULTIVARS (OLEA europaea L.)
}

[27]

\author{
Wafaa T. Saeed ${ }^{1}$; H.Z. Hassan ${ }^{2}$; Saffia M.M. Gazy ${ }^{3}$ and \\ Eglal M.S. Shaban ${ }^{1}$
}

\begin{abstract}
The present work aimed to establish a protocol to minimize the potential effect of in-vitro preservation for 8 months of the two olive cultivars i.e Koronaiki and Kalamata. Three culture conditions (treatments) were chosen to investigate the most suitable one for minimizing somaclonal variations after the process of in vitro preservation. The conditions include MS medium plus mannitol, MS medium plus low temperature and MS medium plus naphthaline acetic acid. RAPD-based fingerprinting was employed to determine the effects of the different chemical constituents and other culture conditions on the extent of somaclonal variations after 8 months of in vitro preservation at the DNA level. Four arbitrary primers (OPA-04, -07, -14 and -16) were successfully utilized to achieve such goal. The obtained results showed that Mannitol has more pronounced effect than the other investigated preservation culture and conditions for decreasing DNA alterations.
\end{abstract}

Key words: Olive, Koronaiki, Kalamata, Preservation, DNA, Primers

\section{INTRODUCTION}

In vitro culture techniques are of a great interest for conserving plant germoplasm in different types of materials (protoplast) cells, tissues, apices, plantlets etc.) and for the use of plant genetic resoureces for plant genetic improvement, food, propagation and other agricultural programs.

Different methods have been used to assess the occurrence of somaconal varia- tions after in vitro propagation or preservation. This information can be obtained by studying morphological traits and other growth characters. The development of randomly amplified polymorphic DNA (RAPD) by Williams et al (1990) generate ultimate potentialities in cultivars identification and discrimination (Hassan et al 2002). This approach have been adopted by many authors to determine the effects of different chemical constituents and other culture conditions on the extent

1- Hort. Res. Inst., Agric. Res. Cent., Min. Agric., Cairo, Egypt

2- Dept. Bot., Fac. Sci., Ain Shams University, Cairo, Egypt

3- Dept. Bot., Fac. Sci., Helwan University, Cairo, Egypt 
of somaclonal variations during in vitro preservation at the DNA level. Zhang $\boldsymbol{e t}$ al (2000) reported that 4-year observations conducted during 1993-96 on forty shoot tip-cultured plantlets of cherry cv. "Xesphye" revealed many RAPD variations. Debabrata et al (2001) used ancymidol as an alternative medium supplement to mannitol for slow-growth conservation of potato microplants in vitro. Ancymidol had a beneficial effect on culture viability after prolonged maintenance in vitro. Genetic stability of potato microplants conserved in ancymidol media was evaluated using RAPD fingerprints. Ancymidol did not induce any detectable genetic variations in genomic DNA as visualized by the absence of either any additional RAPD fragment or alterations in RAPD fragment patterns. Soniya et al (2001) examined genetic stability in tissue-cultured tomato plants by RAPD analysis. Picloram was used for the first time as alternative auxin, along with benzyladenine (BA) for callus induction in tomato. DNA samples from the mother plant and 11 randomly selected regenerated plants, obtained from a single callus, were subjected to RAPD analysis for the detection of putative somaclones. Six arbitrary decamer primers produced polymorphic amplification products. In this set of experiments, 15 non-parental bands were observed. Hao et al (2002) used RAPD analysis to detect DNA sequence variation in regenerated sweet orange (Citrus sinensis) plants derived from the embryogenic callus preserved for a long time. No difference in banding patterns was detected. Helliot et al (2002) used RAPD analysis to evaluate the genetic stability of Prunus ferlenain Plumina plants regenerated from cryopreserved apices. No genetic change was detected among the plantlets regenerated from frozen apices compared with the nonfrozen material. This result suggested that the procedure used for Prunus cryopreservation could be used for long-term conservation. Le et al (2002) used in vitro cultures to built up a collection of Swiss potato genotypes, in order to store plant material in a disease-free environment and to supply, when it is necessary, healthy plants ready for large-scale distribution. At the same time, the identification of a range of varieties, also being achieved through molecular techniques (RAPD and AFLP), enables the conformity of the plant material, which has been stored and propagated to be confirmed. The objective of this work to minimize somaclonal variation effect in vitro preservation of Koronaiki and Kalamata olive cultivars.

\section{MATERIAL AND METHODS}

Two olive cultivars i.e Koronaiki and Kalamata were used in this investigation. Samples for each cultivar were kindly supplied by the Horticulture Research Institute, Agricultural Research Center, Giza, Egypt. After culturing on Murashige and Skoog media (MS) (1962) medium for Kalamata cv., and modified MS medium (Fiorino and Leva 1986 and Charri et al 1999) supplemented with glutamine $(200 \mathrm{mg} / \mathrm{L})$, glycine $(2 \mathrm{mg} / \mathrm{L})$, myo-inositol $(100 \mathrm{mg} / \mathrm{L})$. for Koronaiki, cv., the obtained shootlet of the in vitro plantlets were aseptically microcutting (8-12 mm long) and used as sources of the explants to serve in all of the preservation treatments for 8 months storage period as follow:

* Low temperature: the in vitro cultures were kept in refrigerator at $4^{\circ} \mathrm{C}$ under dark conditions. 
* Mannitol sugar $\left[\mathrm{CH}_{2}(\mathrm{OH}) \cdot(\mathrm{CHOH})_{4}\right.$ $\left.\mathrm{CH}_{2} \mathrm{OH}\right]$ was used as an osmotic active compound applied to media using $15 \mathrm{~g} / \mathrm{l}$.

* Naphthaline acetic acid (NAA) at $0.1 \mathrm{mg} / \mathrm{l}$.

The above mentioned chemical were added to the detrmined preservation media before adjusting Ph. 5.7. Then about $0.2 \mathrm{~g}$ of these preserved tissues were used for DNA extraction following the Dellaporta method (Dellaporta $\boldsymbol{e t}$ al 1983) as follows:

About $0.1 \mathrm{gm}$ (fresh weight) of plant tissues was ground to fine powder in liquid $\mathrm{N}_{2}$ in a mortar. Before the tissue thawed, $1 \mathrm{ml}$ extraction buffer $(100 \mathrm{mM}$ Tris- $\mathrm{HCl} \mathrm{pH}$ 8.0, $50 \mathrm{mM}$ EDTA and $0.5 \mathrm{M} \mathrm{NaCl}$ ) and $0.2 \mathrm{ml} 20 \%$ SDS were added. The mixture was incubated at $65{ }^{\circ} \mathrm{C}$ in water bath for 20 minutes. Then 1 $\mathrm{ml}$ of phenol, chloroform and isoamyl alcohol (25:24:1) was added. Centrifugation was performed at $10,000 \mathrm{rpm}$ for 10 minutes. The supernatants of each sample were transferred separately to a new tubes, then $1 \mathrm{ml}$ of chloroform and isoamyl (24:1) was added. Centrifugation was performed at $10,000 \mathrm{rpm}$ for 10 minutes. The supernatants of each sample were transferred separately to a new tube, then $1 \mathrm{ml}$ of isopropanol was added and then kept overnight in freezer. Centrifugation was performed at $10,000 \mathrm{rpm}$ for 10 minutes. The resulted pellets containing DNA were re-suspended in $1 \mathrm{ml}$ ethanol. Centrifugation was performed at $10,000 \mathrm{rpm}$ for 2 minutes. The DNA pellets were re-suspended in $200 \mu 1$ TE (10 mM Tris-HCl pH 8.0 and 1 mM EDTA) buffer. DNA was quanti- tated by spectrophotometer and gel electrophoresis.

A total of fifteen 10-mer random DNA oligonucleotide primers were independently used in the PCR reactions according to Williams et al (1990). The primers are from Operon Kit (Operon Tech. Inc., USA). Only Five primers were generated reproducible polymorphism in the DNA profiles. Each experiment was repeated two times and only stable products were scored. The following are the code and sequences of these primers.

\begin{tabular}{cc} 
Primer code & \multicolumn{1}{c}{ Sequences } \\
OPA-04 & 5- AGT CAG CCA C -3 \\
OPA-07 & 5- CAG CAC TGA C- 3 \\
OPA-14 & 5- AGC ATG GCT C- 3 \\
OPA-16 & 5 - TCG GCG GTT C- 3
\end{tabular}

Amplification was performed in $25 \mu 1$ reaction volume containing the following:

* Primer

* Template DNA

$2.5 \mu \mathrm{l}$

* Sterile water

$2.3 \mu \mathrm{l}$

$7.7 \mu \mathrm{l}$

* 2 x Ready Mix RED Taq PCR $12.5 \mu \mathrm{l}$ Reaction mix. It consists of the follwing:

* $20 \mathrm{mM}$ Tris- $\mathrm{HCl}(\mathrm{pH} 83)$

* $100 \mathrm{mM} \mathrm{KCl}$

* $3 \mathrm{mM} \mathrm{MgCl} 2$

$* 0.002 \%$ gelatin

* 0.4 mM dNTBs mix (dATP, dCTP, dGTP and dTTP)

* stabilizers

* 60 units Taq DNA polymerase /ml.

Each of the reaction mixtures was overlaid with a drop of light mineral oil per sample. Amplification was carried out in Perkin Elmer Gene Amp PCR thermocycler. The optimal condi- 
tions for PCR amplification was as follows: an initial 4 minutes denaturation step at $95^{\circ} \mathrm{C}$ followed by 35 cycles of 45 second at $94^{\circ} \mathrm{C}, 1$ minute at $37^{\circ} \mathrm{C}$ and 2 minutes at $72^{\circ} \mathrm{C}$, with a final extension step at $72^{\circ} \mathrm{C}$ for 12 minutes.

A volume of $10 \mu \mathrm{l}$ of the RAPD products were electrophoresed in $1.4 \%$ agarose gel. The gel was prepared by adding $1.4 \mathrm{~g}$ agarose to $100 \mathrm{ml}$ of $1 \mathrm{X}$ TBE (0.04 M Tris-acetate, $1 \mathrm{mM}$ EDTA, $\mathrm{pH} 8$ ), followed by boiling in water bath. Then $0.5 \mu \mathrm{g} / \mathrm{ml}$ ethidium bromide was added to the melted gel. The melted gel was poured in the tray of mini-gel apparatus and the comb was inserted immediately. The comb was removed when the gel become hardened. The electrophoresis buffer (1X TBE) was covered the gel. About $10 \mu \mathrm{l}$ of DNA amplified product was loaded in each well and run at $60 \mathrm{~V}$ for about 45-75 minutes. The gels were visualized and photographed by gel documentation system (GelDoc BioRad 2000) under UV transilluminator.

\section{RESULTS AND DISCUSSION}

In this study RAPD-based fingerprinting was employed to determine the effects of different chemical constituents of media and other preservation conditions on the extent of somaclonal variation during in vitro preservation at the DNA level. Two new-imported olive cultivars Koronaiki and Kalamata were chosen to investigate the possible mutagenic effects (somaclonal variations) of the different tissue culture conditions in order to minimize it. Four arbitrary primers (OPA-04, $-07,-14$ and -16) were successfully utilized to achieve such goal. These primers succeeded to amplify reproducible DNA products. As described before modified
MS medium was the most suitable one for micro-propagation of Koronaiki cultivar whereas, MS medium was optimal one for Kalamata cultivar. Three culture conditions (treatments) were also chosen to investigate the most suitable one for minimizing somaclonal variations after the process of in vitro preservation.

For both Koronaiki and Kalamata cultivars and for each tissue preservation conditions the amplification products generated by each primer were scored. Only clear and unambiguous DNA bands were included in the analysis. The shared bands between RAPD banding patterns of each tissue culture conditions and control as well as the altered ones were recorded and the percentage of alterations were determined.

Figure 1 demonstrates the effect of the tested media on the DNA banding patterns of the two preserved olive cultivars. Primer OPA-07 is the most effective than the three other primers for detecting alterations after the process of tissue preservation as compared with control samples. Many pronounced alterations were detected in the RAPD profile of the two olive cultivars that generated by this primer. The alterations involved are: the generation of novel bands, the disappearance of other bands and the change in band's intensity. Table (1) reveals that the alterations percentage scored by the primer 07 after 8 months in vitro preservation for Koronaiki explants on modified MS media plus mannitol, plus low temperature or plus naphthaline acetic acid were 44.44, 36.84 and $77.78 \%$, respectively. Similarly, the percentages of alterations scored in the RAPD profiles of the preserved Kalamata tissues on MS media plus mannitol, plus low 
Figure 1. Effect of in vitro preservation on the RAPD profile of the two olive cultivars Koronaiki and Kalamata generated by the four OPA-04, -07, -14 and 16 primers.

Lane : M DNA Marker

Lane: 1 Control Lane : 5 Control

Lane: 2 Modified MS media plus Lane: 6 MS media plus mannitol mannitol

Lane : 3 Modified MS media plus low Lane : 7 MS media plus low temperature temperature

Lane : 4 Modified MS media plus Lane: 8 MS media plus naphthaline naphthaline acetic acid acetic acid

Arab Univ. J. Agric. Sci., 13(2), 2005 
Table 1. The percentage of the altered bands detected by the OPA 04, 07, 14 and 16 primers after preservation of the Koronaiki olive cultivar for 8 months on any of Modified MS media plus (1) mannitol, (2) low temperature or (3) naphthaline acetic acid

\begin{tabular}{|c|c|c|c|c|}
\hline & Total bands & $\begin{array}{l}\text { Mono- } \\
\text { morphic } \\
\text { bands }\end{array}$ & $\begin{array}{l}\text { Poly- } \\
\text { morphic } \\
\text { bands }\end{array}$ & $\begin{array}{c}\% \text { of altered } \\
\text { bands }\end{array}$ \\
\hline \multicolumn{5}{|c|}{ (1) Modified MS media plus mannitol } \\
\hline Primer 04 & 14 & 14 & 0 & 0.00 \\
\hline Primer 07 & 18 & 10 & 8 & 44.44 \\
\hline Primer 14 & 8 & 8 & 0 & 0.00 \\
\hline Primer 16 & 19 & 19 & 0 & 0.00 \\
\hline Pooled effect & 59 & 51 & 8 & 13.56 \\
\hline \multicolumn{5}{|c|}{ (2) Modified MS media plus low temperature } \\
\hline Primer 04 & 14 & 14 & 0 & 0.00 \\
\hline Primer 07 & 19 & 12 & 7 & 36.84 \\
\hline Primer 14 & 9 & 8 & 1 & 11.11 \\
\hline Primer 16 & 19 & 17 & 2 & 10.53 \\
\hline Pooled effect & 61 & 51 & 10 & 16.39 \\
\hline \multicolumn{5}{|c|}{ (3) Modified MS media plus naphthaline acetic acid } \\
\hline Primer 04 & 14 & 14 & 0 & 0.00 \\
\hline Primer 07 & 18 & 4 & 14 & 77.78 \\
\hline Primer 14 & 9 & 7 & 2 & 22.22 \\
\hline Primer 16 & 19 & 17 & 2 & 10.53 \\
\hline Pooled effect & 60 & 42 & 18 & 30.00 \\
\hline
\end{tabular}


Table 2. Number and types of the amplified DNA bands as well as the percentage of the altered bands detected by the OPA 04, 07, 14 and 16 primers after preservation of the Kalamata olive cultivar for 8 months on any of MS media plus (1) mannitol, (2) low temperature or (3) naphthaline acetic acid

\begin{tabular}{|c|c|c|c|c|}
\hline & $\begin{array}{l}\text { Total } \\
\text { bands }\end{array}$ & $\begin{array}{l}\text { Mono- } \\
\text { morphic } \\
\text { bands }\end{array}$ & $\begin{array}{l}\text { Poly- } \\
\text { morphic } \\
\text { bands }\end{array}$ & $\begin{array}{c}\% \text { of altered } \\
\text { bands }\end{array}$ \\
\hline \multicolumn{5}{|c|}{ (1) MS media plus mannitol } \\
\hline Primer 04 & 8 & 8 & 0 & 0.00 \\
\hline Primer 07 & 21 & 19 & 2 & 9.52 \\
\hline Primer 14 & 8 & 7 & 1 & 12.50 \\
\hline Primer 16 & 13 & 12 & 1 & 7.69 \\
\hline Pooled effect & 50 & 46 & 4 & 8.00 \\
\hline \multicolumn{5}{|c|}{ (2) MS media plus low temperature } \\
\hline Primer 04 & 8 & 8 & 0 & 0.00 \\
\hline Primer 07 & 21 & 9 & 12 & 57.14 \\
\hline Primer 14 & 8 & 7 & 1 & 12.50 \\
\hline Primer 16 & 15 & 12 & 3 & 20.00 \\
\hline Pooled effect & 52 & 36 & 16 & 30.77 \\
\hline \multicolumn{5}{|c|}{ (3) MS media plus naphthaline acetic acid } \\
\hline Primer 04 & 10 & 8 & 2 & 20.00 \\
\hline Primer 07 & 20 & 6 & 14 & 70.00 \\
\hline Primer 14 & 9 & 7 & 2 & 22.22 \\
\hline Primer 16 & 15 & 12 & 3 & 20.00 \\
\hline Pooled effect & 54 & 33 & 21 & 38.89 \\
\hline
\end{tabular}


temperature or plus naphthaline acetic acid reached 9.52, 57.14 and $70.00 \%$, respectively (Table, 2 ).

Tables, (1) and (2) show that adding mannitol to MS medium had a pronounced effect for decreasing DNA alterations as compared to other investigated preservation conditions. The pooled effect on the Koronaiki olive cultivar detected by the four utilized primers reached the lowest value ( $13.56 \%$ ) after preservation on MS media plus mannitol whereas the highest pooled effect $(30.00$ $\%$ ) observed after preservation on MS medium plus naphthaline acetic acid (Table 1). Similarly, Table (2) shows that the pooled effect on the Kalamata olive cultivar detected by the four utilized primers reached the lowest value( $8.00 \%$ ) after preservation on MS medium plus mannitol whereas the highest pooled effect value $(38.89 \%)$ exhibited after preservation on MS medium plus naphthaline acetic acid.

Callus is a potential source of genetic instability and represents an undesirable feature in clonal propagation protocols and in vitro preservation. After a basic tissue culture system has been developed for a given species, the problem of somaclonal variations has been emerged. This report presents a protocol to minimize the potential effect of the chemical constituents of the media used for micropropagation and in-vitro preservation of the two olive cultivars Koronaiki and Kalamata.

Detection of somaclonal variation requires a precise and simple method, which reveals changes at the gene level. To achieve such goal, RAPD analysis was employed to detect these changes at the DNA level. In the present study, four arbitrary primers (OPA-04, -07, -14 and -
16) were succeeded to amplify reproducible DNA products.

The advantage of RAPD analysis in this study is that it covers the entire genome; therefore it provides sufficient information about structural changes that might be occurred inside the genome due to different chemicals involved in tissue culture media. In this regard, Williams et al (1990) showed that RAPD markers cover the entire genome, revealing coding or noncoding regions, repeated or singlecopy sequences. Also, Schnell et al (1995) reported that the arbitrary nature of the primer resulted in amplified DNA products representing random samples of the entire genome.

The observed alterations in the RAPD profiles recorded after in vitro culture preservation of explants for Koronaiki and Kalamata olive cv. might be due to structural changes in the genomic DNA of these cultivars. This conclusion is in accordance with Gozukirmizi et al (1992) who used the primer-globin gene (-115 to -95 sequence) for fingerprinting barley somaclonal plants. Analysis of the amplified products revealed significant differences in the pattern of RAPDs from different regenerants. Similarly, Brar and Jain, (1998) showed that the genetic instability of in vitro cultured crops as revealed by the considerable variation in RAPD products might be due to the mutagenic effect of 2,4-D. Also, Aly and Saker (1998) reported that analysis of regenerated faba bean plants revealed a significant frequency of DNA polymorphism (i.e. somaclonal variation) among the somatic embryo-derived plants. Badr et al (1998) used RAPD technique to detect somaclonal variations in regenerated pea and kidney bean plants. DeVerno et al (1999) regenerate trees from six 
white spruce (Picea glauca) embryogenic clones after cryopreservation for 3 and 4 years and evaluate genetic stability using RAPD fingerprints. Somaclonal variation was detected in some in vitro embryogenic cultures, 2 and 12 months after they were re-established following cryopreservation. The DNA fingerprints as revealed by RAPD have proved useful in detecting somaclonal variations among wheat plants regenerated from protoplasts (Brown et al 1993), micropropagated plants of Populus eltoids (Rani et al 1995) and sugarcane plants regenerated from embryogenic callus (Taylor et al 1995). The results of those authors indicated that RAPD technique is an efficient and effective tool for determining DNA alterations due to chemicals utilized for in vitro culture media.

This interpretation was reinforced by Michelmore et al (1991) who reported that polymorphism in RAPD profile results from base changes that alter primerbinding sites. Similarly, Lu et al (1996) revealed that polymorphism might be due to structural changes in the genomic DNA that alter the distance between two annealing sites, delete an existing site or insert a new one. Also, Yang and Quiros (1993) reported that, the intensity of DNA bands depends on the starting copy number of a particular DNA sequence within the genome. Therefore, the alterations in band's intensity could be interpreted on the basis of alterations of some DNA sequences.

In this study, the avoiding of long time for regeneration lead to minimizing of somaclonal variations. In this regard Aly and Saker (1998) reported that the relatively high frequency $(30 \%)$ of somaclonal variation detected in regeneration of faba bean is due to the extended in vitro interval needed before achieving plant regeneration. Moreover, avoiding the use of 2,4-D in the utilized media counteracts the formation of high frequency of somaclonal variations in the regenerated olive cultivars. It could be also due to the mutagenic effect of 2,4-D (Brar and Jain, 1998), especially with explants subjected to long-term exposure (four months). The experimental material analyzed were the first group of regenerants obtained using this regeneration protocol and used to evaluate the regenerants.

\section{REFERENCES}

Aly, M.A.M. and M.M. Saker (1998). Somaclonal variation detected in somatic embryos-derived faba bean plants by RAPD-based fingerprinting. $3^{\text {rd }}$ Arab Conference. Modern Biotech. \& Areas of Application in the Arab World, pp. 697-707. Cairo, Egypt.

Badr, A.; M.K. El-Bahr; S.A. Ghanem; H.A. Moursy; M.M. Saker and F. Sala (1998). DNA fingerprints of RAPD products as a measure of genetic variation of in vitro cultured pea and kidney bean. Egypt. J. Genet. Cytol. 27: 123-134.

Brar, D.S. and S.M. Jain (1998). Somaclonal variation: Mechanism and application in crop improvement. In: $\mathbf{S}$. M. Jain., D.S. Brar. and B.S. Ahloowalia. (eds) Somaclonal Variation and Induced Mutations in Crop Improvement pp.15-37, Kluwer, Dordrecht. Brown, H.P.; D.F. Lange; E. Kranz and H. Lorz (1993). Analysis of single protoplast and regenerated plants by PCR and RA PD technology. Mol Gen Genet. 237: 311-317. 
Charri, A.; A. Trigui; N. Drira; I.T. Metzidakis and D.G. Voyaitzis (1999). Micropropagation of Tunisian cultivars of olive trees: Preliminary results. Acta Hortculturae. 474: 79-81.

Debabrata, S.; S.K. Chakrabarti; P.S. Naik and D. Sarkar (2001). Slowgrowth conservation of potato microplants: efficacy of ancymidol for longterm storage in vitro. Euphytica. 117(2): 133-142.

Dellaporta, S.L.; J. Wood and J.B. Hicks (1983). A plant DNA mini preparation Version III. Plant Mol. Biol., Rep. 1: 19-21.

DeVerno, L.L.; Y.S. Park; J. M. Bonga and J.D. Barrett (1999). Somaclonal variation in cryopreserved embryogenic clones of white spruce [Picea glauca (Moench) Voss.]. Plant-Cell-Reports. 18 (11): 948-953.

Fiorino, P. and R. Leva (1986). Investigation on the micropropagation of the olive (Olea europea L.) influence of some mineral elements on the proliferation and rooting of explants. Olea. 17: 101-104.

Gozukirmizi, N.; S. Ari; F. Gurel; F. Gumusel and B. Cirakoglu (1992). Fingerprinting barley genome using PCR with arbitrary primer in barley plants regenerated from tissue culture. In: You, C. B.; Z.L. Chen, and Y. Ding, (eds): Biotechnology in Agriculture, Proceedings of the First Asian-Pacific Conference on Agricultural Biotechnology. pp. 185188, Beijing, China.

Hao, Y.; X. Deng; Y.J. Hao and X.X. Deng (2002). Occurrence of chromosomal variations and plant regeneration from long-term-cultured citrus callus. In Vitro Cellular and Developmental Biology Plant 38(5): 472-476.

Hassan, H.Z.; Nadia M. Mansour and Elham A. Abd El-Hady (2002). Molec- ular genetic identification of some selected local peach (Prunus persica L.) cultivars at Dakhalia. Egypt. J. Biotechnol. 11: 282-304.

Helliot, B.; D. Madur; E. Dirlewanger; M.T. de Boucaud; M.T. de Boucaud (2002). Evaluation of genetic stability in cryopreserved Prunus. In-Vitro-Cellular and Developmental Biology Plant. 38(5): 493-500.

Le, C.L.; D. Thomas and L. Nowbuth (2002). In vitro conservation and identification of potato (Solanum tuberosum L.) varieties cultivated in Switzerland. Revue Suisse d'Agriculture. 34 (3): 133-136.

Lu, J.; M.R. Knox; M.J. Ambrose; J.K.M. Brown and T.H.N. Ellis (1996). Comparative analysis of genetic diversity in pea assessed by RFLP- and RAPDbased methods. Theor. Appl. Genet. 93 : 1103-1111.

Michelmore, R.W.; I. Paran and R.V. Kesseli (1991). Identification of markers linked to disease-resistance genes by bulked segregant analysis: a rapid method to detect markers in segregating populations. Proc. Natl. Acad. Sci., 88: 98289832.

Rani, V.; A. Parida and N.S. Raina (1995). Random amplified polymorphic DNA (RAPD) markers for genetic analysis in micropropagated plants of Populus eltoids Marsh. Plant Cell Repts. 14: 454464.

Schnell, R.J.; C.M. Ronning and R.J. Knight (1995). Identification of cultivars and validation of genetic relationships in Mingifera indica L. using RAPD markers. Theor. Appl. Genet. 90: 269-274.

Soniya, E.V.; N.S. Banerjee and M.R. Das (2001). Genetic analysis of somaclonal variation among callusderived plants of tomato. Current Science. 80 (9): 1213-1215. 
Taylor, P.W.J.; T.A. Fraser; H.L. Ko and R.J. Heirry (1995). RAPD analysis of sugarcane during tissue culture. In: Terzi M.; R. Cella and A. Falavigna (eds). Current Issues in Plant Molecular and Cellular Biology. pp. 241-246), Kluwer Academic Press, Boston, USA.

Williams, J.G.K.; A.R. Kubelk; K.J. Livak; J.A. Rafalski and S.V. Tingey (1990). DNA polymorphism amplified by arbitrary primers are useful as genetic markers. Nucl. Acid Res. 18: 6231-6235.
Yang, X. and C. Quiros (1993). Identification and classification of celery cultivars with RAPD markers. Theor. Appl. Genet. 86: 205-212.

Zhang K.; L. Qin.; F. Yang; K. Lin-; X. Zhang; K.C. Zhang; L.Y. Qin; F.Y. Yang; K. Lin.; X.M. Zhang (2000). Morphological and RAPD evaluation of an early ripening variant from apical bud tissue culture of sweet cherry. J. Fruit Science. 17 (3): 225-227.

بحلة اتحاد الجامعات العربية للدراسات والبحوث الزراعية ، جامعة عين شمس ، القاهرة ، 13(2) ، 441 - 452 ، 2005 تأثير معاملات الحفظ داخل المعمل على التباين في التضاعف العثوائي لأجزاء من DNA لصنفي الزيتون الكروناكى والكلاماتا

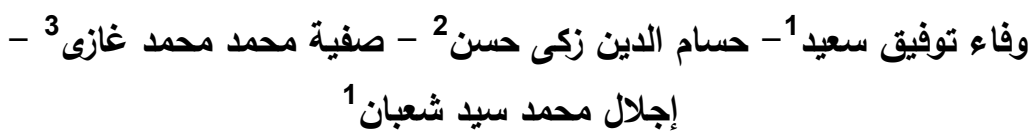$$
\text { 1- قسم الزيتون - معهل بحوث البساتين - مركز البحوث الزراعية - وزارة الزراعة - جيزة - مصر }
$$$$
\text { 2- قسم النبات - كلية العلوم - جامعة عين شمس - القاهرة - مصر الندر }
$$$$
\text { 3- قسم النبات - كلية العلوم - جامعة حلوان - القاهرة - مصر عرد }
$$

يهدف هذا البحث الى تقليل التباين لصنف الكروناكى وبيئة

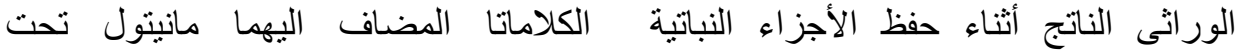

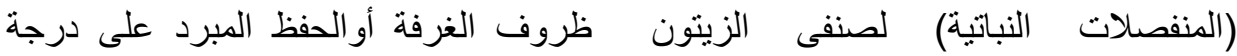

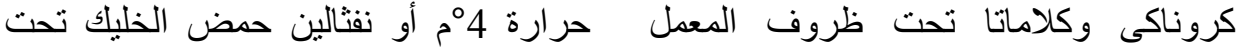

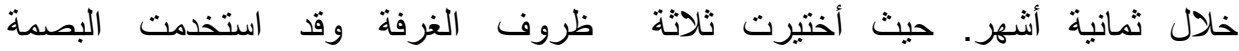

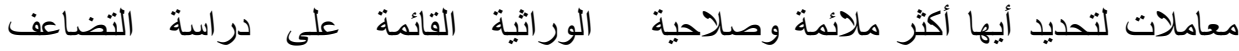

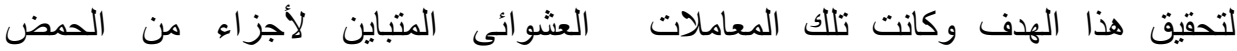

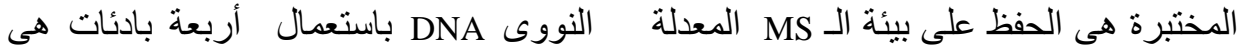


الكروناكى و الكلاماتا مقارنة بالبادئات الثلاثة الأخرى ( OPA- 04, 07- 14 and

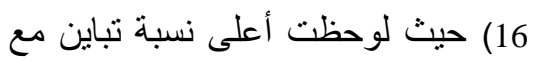
هذا البادىه لصنفى الزيتون بغض النظر عن نوع بيئة وظروف الحفظ. 2- أوضحت النتائج أن أقل نسبة تبـاين أثناء

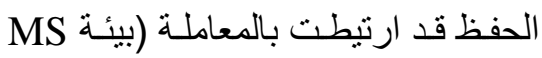

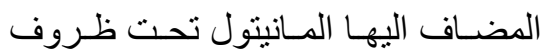
الغرفـة) وذلك لكلٍ مـن صـنفى الزيتـون

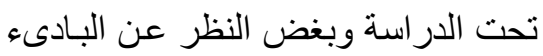
المستعمل للإستدلال على هذا التباين.
ولإستدلال (OPA- 04, 07, 14 and -16) على حدوث تباينات ور اثية من عدمة وكذللك للحكم على معاملات تلك التباينات ... * ويمكن أن نوجز أهم النتائج المنحصل

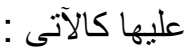
S'-CAP CAC', ) OPA - 07 البادئ : 07 (TGA C-3' ومن ثم صلاحيته للحكم على حدوث ونسبة التباين الوراثى فئ الأجزاء

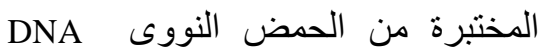
للعينات المحفوظة من صنف الزيتون

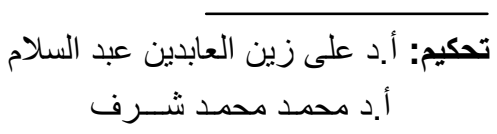

